\title{
Yesterday Once More: Hong Kong-China Coproductions and the Myth of Mainlandization
}

\author{
Gary Bettinson, Lancaster University \\ g.bettinson@lancaster.ac.uk
}

\begin{abstract}
Since Ackbar Abbas theorized Hong Kong as a space of cultural 'disappearance' in the mid-1990s, critics have debated the extent to which local cultural forms have continued to recede, particularly as a corollary of Hong Kong's increasing subjection to mainlandization. For several critics, the region's cinema has already vanished from view, only to re-emerge in a brand new, distinctly Sinicized guise - that of 'post-Hong Kong cinema,' a mode of predominantly coproduced filmmaking that effaces traditional Hong Kong aesthetics and routines of film practice. So thoroughly has Hong Kong cinema been subsumed to China that its once 'unique' and 'singular' identity is no longer discernible. The shackles of PRC censorship now stifle free expression; Hong Kong's classic genres have become obsolete; and the PRC's vogue for 'main melody' films and the dapian ('big film') has straitened Hong Kong cinema's range of storytelling options. Today, critics contend, Hong Kong filmmakers are severely constrained by Mainland bureaucracy and the exigencies of the China market.

This article seeks to challenge these assumptions, contesting a set of apparent truisms concerning Mainland censorship, Hong Kong-China coproductions, and the dissipation or disappearance of Hong Kong's local cinema and identity. The theory of mainlandization, I submit, denies the durability of Hong Kong's standardized craft practices; its aesthetic traditions; and the facile ingenuity of its filmmakers.
\end{abstract}

Keywords: Hong Kong-China coproductions; mainlandization; Hong Kong localism; PRC censorship; Hong Kong film style; film authorship.

Biographical note: Gary Bettinson is Senior Lecturer in Film Studies at Lancaster University. He is the author of The Sensuous Cinema of Wong Kar-wai (Hong Kong UP 2015), co-editor of The Poetics of Chinese Cinema (Palgrave Macmillan, 2016) and Hong Kong Horror Cinema (Edinburgh UP, 2018), and editor-in-chief of Asian Cinema (Intellect).

Word count: 7502 


\section{Yesterday Once More: Hong Kong-China Coproductions and the Myth of Mainlandization}

Over the past twenty-five years, Hong Kong-PRC coproductions have traced a steep upward trajectory. Buoyed by the Joint Declaration in 1984, Chinese filmmakers produced a smattering of such films in the early to mid-1980s. A brief hiatus ensued in the wake of the 1989 Tiananmen massacre, followed by another spike in the pre-handover years. ${ }^{1}$ (Salient titles include Stanley Kwan's Centre Stage [1991], Tsui Hark's Once Upon a Time in China [1991], and Wong Kar-wai's Ashes of Time [1994].) After the 1997 handover, the Closer Economic Partnership Arrangement (CEPA), a free trade deal signed in 2003, triggered an unprecedented surge in Hong Kong-PRC coproductions. By 2007 mainland coproductions accounted for almost half of Hong Kong's annual film output; within a few years they had outstripped local productions, a trend that persists today. At the same period, many Hong Kong directors - alive to the rapid exponential growth of China's theatrical market established production bases in Beijing and Shanghai. Even holdouts like Johnnie To, his production company (Milkyway Image) a beacon of local filmmaking during the industry's lean years, came to forge partnerships with movie studios across the border.

Many commentators - fans, cinephiles, critics, scholars - castigate the new coproductions. Arriving on the heels of Hong Kong's bedizened 'golden age' - a boom period yielding a welter of local landmarks including A Better Tomorrow (1986), Rouge (1988), The Killer (1989), and Days of Being Wild (1990) - the post-handover coproductions looked pedestrian by comparison, mangled by mainland censorship. The censorship criteria are well-known. Prohibited is the depiction of ghosts, time travel, reincarnation, the Falun Gong cult, and other affronts to post-Enlightenment thinking. Invoking 'the three T's' Taiwan, Tibet, Tiananmen Square - is forbidden, construed as a threat to national unity and 'official' PRC history. Beijing's corridors of power must be portrayed as spotless; figures of authority must not be shown to be 'in any way corrupt or bad or wrong.' ${ }^{2}$ Over the depiction of sex hovers a vigilant puritanism: graphically sexual imagery is not tolerated, homosexuality infrequently addressed. Violence must be moderate.

Mainland coproductions must navigate this tranche of taboos and more. Under the auspices of state bodies (until recently SARFT), ${ }^{3}$ the de facto censorship criteria can be erratic and mystifying, not to say bizarre. State censors, for instance, refused Stephen Chow's Shaolin Soccer (2001) mainland theatrical distribution despite its coproduction status. The official justification for the ban - that Shaolin Soccer 'makes too much fun of football' strains credulity. ${ }^{4}$ Critics find profoundly troubling both the exhaustive production monitoring, which curtails the creative autonomy of Hong Kong filmmakers working with and within the PRC, and the monopoly of coproductions, out of which grows fear of 'mainlandization' and the cultural erasure of Hong Kong. For some observers, Hong Kong cinema now teeters on the edge of extinction. For others, it has already entered the age of 'post-Hong Kong cinema' (Lee 2012). On the latter view, Hong Kong cinema has been mainlandized out of existence. The obsolete Hong Kong director resorts to 'survival 
strategies,' ceding creative autonomy at every turn, and robotically succumbing to selfcensorship (or what the state authorities euphemistically call 'self-discipline'). ${ }^{5}$

In this article I attempt to redress the mainlandization thesis sketched above. Both strong and soft versions of this thesis - i.e. that Hong Kong cinema is either defunct or moribund, on the brink of 'disappearance' - dominate critical thinking on contemporary Hong Kong cinema. If we are to take the full measure of the coproduction model, however, we need to nuance several of the key criticisms routinely aimed against it. I rehearse these criticisms in the following section.

\section{The Mainlandization Thesis}

The chief criticisms of Hong Kong-PRC coproductions run as follows:

1. China's coproduction system stymies artistic freedom. It does so, most conspicuously, by virtue of its draconian prohibitions, the erratic enforcement of which 'creates an unfavourable environment for cultural creativity' (Zhou 2015: 239). Curbing free expression, China coproductions refuse Hong Kong filmmakers 'the fertile ground of creative freedom that they had experienced in 1990s Hong Kong' (Lee 2012: 191). Hong Kong's golden era, unfettered by censorship, proved artistically fecund, but the post-handover years - beset by mainland meddling - have pushed Hong Kong toward cultural desertification. A principal casualty here is the Hong Kong auteur. According to critic Bono Lee, the China coproduction system downgrades auteurs to the rank of metteur-en-scène, mere 'technicians who follow orders' (194). Stifling the auteur's 'personal intent,' Lee argues, is but one stratagem in a general process of 'de-Hong Kong-isation' fostered by Beijing. Perhaps surprisingly, Hong Kong auteurs are complicit in this act of (self-)abnegation. Lee imputes to China-bound filmmakers not so much an artistic motivation as a 'mercenary' one. Coveting the vast mainland market, Hong Kong auteurs accede to state proscriptions, relinquish auteurist priorities, and transmogrify into "slick producer[s] and planner[s]" (194).

2. Coproductions have comprehensively mainlandized Hong Kong film aesthetics. No longer are Hong Kong films distinguished by a local 'spirit,' 'flavour,' or 'aura.' 6 The 'eccentric traits' and 'idiosyncratic Hong Kong characteristics' so integral to this cinema's popular appeal are nowhere evident in the new coproductions. ${ }^{7}$ Signature traits of story and style have been usurped by mainland aesthetics, eventuating in 'the loss of Hong Kong style' (Chu 2015: 115). The new coproductions cue elegies for local filmmaking: traditional Hong Kong cinema has 'not only changed beyond recognition, but [has] gone for good' (Lam 2011: iv). In its stead, claims Bono Lee, are post-Hong Kong films, coproduced ventures that 'suppress...Hong Kong characteristics' in favour of mainland settings, subject matter, and stars (Lee 2012: 193). Alternative critical voices offer a more moderate, if no less fatalistic, prognosis - namely, that Hong Kong's trademark aesthetic, though not yet effaced, is gradually and inexorably fading. On both accounts, Hong Kong cinema has been mortally mainlandized, its long-standing aesthetic traditions radically diluted or displaced by PRC storytelling. 
How did this happen? For one thing, state censorship hobbled Hong Kong's vintage genres. From supernatural horror to corrupt-cop crime dramas, from vulgar comedies to the 'ultra-violent' genres of heroic bloodshed, kung fu, and wuxia, the local cinema's genre specialisms found an inhospitable milieu in the puritanical nation-state. At the same period, investors began to favour anodyne material. Aspiring to the mainland market, they strategically eschewed censorable subject matter. Suddenly ghost stories, ribald comedies, and gritty policiers became nonstarters. Consequently, says director Pang Ho-cheung, 'a lot of genres from the past gradually [began] disappearing. ${ }^{8}$ By discharging Beijing's content controls, China's coproduction model has severely truncated the suite of storytelling options previously available to Hong Kong filmmakers (Leung 2013: 131). Even worse, the PRC has subsumed these filmmakers to the national cause. Peter Chan, Tsui Hark, Gordon Chan and others are recruited to direct 'main melody' films, bombastic vessels of Communist ideology, which now supplant Hong Kong's classic genres. Lavishly expensive, politically conformist, and devoid of artistic innovation, these coproductions are seen as a betrayal of Hong Kong film culture - a repudiation of the local industry's proud heritage of formal experimentation, stylistic exuberance, and creative free expression.

\section{Coproductions have rendered local craft practices obsolete. The scourge of} mainlandization has vanquished not only Hong Kong cinema's aesthetic traits but its traditional work routines as well. Previously free from Orwellian bureaucracy, Hong Kong filmmakers now must navigate a morass of mandates, memos, and meetings. Freewheeling spontaneity has given way to fastidious work protocols. Hong Kong plots used to be fashioned on the fly, but now the full-fledged screenplay and plot synopsis have forced improvisatory practices out of commission. Then there is the mainland's average production period, sharply different from the rapid turnaround of local cinema. Before 1997, a Hong Kong quickie could be cranked out within a few weeks; in the 2000s, a coproduction's schedule might balloon to eighteen months, so byzantine is the state's censorship apparatus. Not least, Hong Kong filmmakers needed to adjust to China's bloated budgets and crew sizes, gargantuan by local standards. Once again, critics bewail the loss of local custom. Hong Kong cinema's distinctive work methods - the artisanal routines that yielded the golden era's artistic triumphs - have been jettisoned by a coproduction system firmly anchored in mainland modes of production.

\section{The coproduction system has plunged Hong Kong cinema into artistic decline. As} coproductions came to dominate Hong Kong film output in the early 2000s, the overall quality of Hong Kong cinema nosedived. Seeking to replicate their domestic success in the mainland, Hong Kong directors began cannibalizing their past blockbusters. Alan Mak and Felix Chong's The Silent War (2012) repackaged - and mainlandized - their indigenous megahits Infernal Affairs (2002) and Overheard (2009); Johnnie To's Drug War (2012) remixed signature elements from PTU (2003), The Mission (1999), and Election (2005). These two coproductions proved popular with mainland viewers, but to Hong Kong critics they signalled a palpable artistic regression; the new coproductions were bastardizations, anaemic mutilations of local film style. Thanks to an undemanding mainland audience, Hong Kong filmmakers could coast on self-pastiche. As Esther C. M. Yau observes, 'The 
transferring and adapting process has put many film directors into a low-creativity mode of repackaging' (Yau 2015: 26). For some critics, the inferiority of mainland product owed much to a mercenary pursuit of profit: 'The single-mindedness of making money has exerted adverse impacts [sic] on the quality of co-produced films,' claims Yiu-wai Chu (Chu 2015: 112). The slump in quality struck domestically too. By migrating north, Hong Kong's brightest talents left the local industry depleted. Inevitably the rot of 'brain drain' festered and metastasized, tipping the standards of local cinema into terminal decline. ${ }^{9}$

The erosion of creative freedom, local style, craft traditions, and artistic standards - so much cultural attrition has led to the root-and-branch mainlandization of Hong Kong cinema. So argue the adherents of the mainlandization thesis. In this article I posit an alternative perspective, arguing that critics have overstated the purported mainlandization of Hong Kong cinema as regards both film content and craft practices. Hong Kong cinema's vaunted identity and 'flavour' - to the extent that such phenomena are perceptible - are neither already démodé nor on the cusp of disappearance. Moreover, the coproduction model has rejuvenated and stabilized a flagging local industry. It has done so not only by complementing (rather than supplanting) local filmmaking, but also by expanding (rather than curtailing) Hong Kong filmmakers' menu of creative choice. Hong Kong cinema has changed since 1997, certainly; but its transformation has been far less apocalyptic than the mainlandization thesis maintains.

\section{Craft Continuities}

To be sure, China's coproduction system altered Hong Kong film practice in manifest ways. At CEPA's behest, at least one third of a coproduction's personnel now had to hail from the People's Republic; Hong Kong filmmakers were urged to 'think big' (Lee 2012: 191), the scale of production dwarfing that of local films (a coproduction might host more than 600 crew members as compared to fewer than 200 on a domestic film ${ }^{10}$ ); budgets, too, swelled far beyond local norms; and various rounds of censorship, policing every phase of production, needed to be shrewdly negotiated. But these new constraints did not eradicate craft practices fostered in the Cantonese film industry. When Hong Kong directors ventured north, they clung to local work routines. Still today, they rely on Hong Kong craft traditions, stubbornly resisting any temptation to mainlandize film practice. By means of assimilation, subterfuge, circumvention, active resistance, strategic trade-offs and other tactics, these filmmakers preserve local work routines that date back at least to the 1970 s.

What indigenous craft practices have weathered the mainland coproduction process? How have Hong Kong filmmakers, loath to abandon tried-and-proven methods, sought to preserve them? We can start to address these questions with reference to the preproduction phase. From the start of production, Hong Kong filmmakers encountered alien pressures. For several years CEPA mandated a full-blown screenplay, to be churned through SARFT's censorship machinery and, once sanctioned, faithfully adhered to during shooting. Proponents of Hong Kong's customary writing method - the practice of piecemeal plotting, stretching the 
scripting process across all phases of production - initially orchestrated ways to skirt CEPA's script demands. Johnnie To conceived a devilish feint, plying SARFT with counterfeit screenplays. Wholly innocuous and sanitized, these ersatz scripts served their purpose by floating through SARFT's approvals system unmolested. Once granted SARFT's imprimatur, To ditched the faux screenplay and reverted to Hong Kong scripting practice. Other directors adopted this gambit too, but aborted it when SARFT officials awoke to their ruse. ${ }^{11}$ At any rate, the gambit itself is instructive: as a first impulse, Hong Kong filmmakers sought to import local work practices to the mainland - an impulse they did not surrender even after SARFT vetoed the phony screenplay device.

Nothing if not expeditious, Hong Kong filmmakers mastered the rules of the game. Preproduction became an occasion to pre-empt script censorship. 'When I prepare a China coproduction project,' states Pang Ho-cheung, 'I know what the rules are and what topics to avoid.' ${ }^{12}$ Savvy scenarists swerved from 'the three T's' and strategically ducked other taboo subjects. They discovered, too, that depictions of ghosts, crooked cops, and gambling - the marrow of Hong Kong's golden-age movies - could be preapproved if shrewdly packaged. Supernatural beings could be presented on screen provided they were motivated by character psychology: the 'spectre' must be shown to spring from a protagonist's dreamstate, hallucination, or mental disorder. ${ }^{13}$ Moreover, although ghosts per se were prohibited, a fuzzy subset of diabolical creatures (demons, elves, mutated animal spirits - 'everything short of ghosts,' according to producer Nansun Shi ${ }^{14}$ ) met with the censors' approval. Thanks to such nebulous categories, Gordon Chan could mount Painted Skin (2008) - touted as 'China's first ghost film in twenty years' - as a Hong Kong-PRC coproduction. ${ }^{15}$ Shi calls such movies 'quasi-horror films': tethering the source of horror to the secular rather than the supernatural, Hong Kong filmmakers have kept alive a genre of storytelling they mined successfully at home. $^{16}$

Nor did preproduction scripts have to abandon the depraved cop archetype. Police corruption could be dramatized 'if all the corrupt cops in the story were from Hong Kong and all the good cops [were] from the mainland,' observes Gordon Chan. ${ }^{17}$ Depictions of gambling - an activity outlawed in mainland China but ubiquitous on Hong Kong screens could be scripted under similar conditions, as when Wong Jing's From Vegas to Macau (2014) portrays gambling as a 'foreign' (i.e. Hong Kong) affliction. Here, then, is something the notion of mainlandization fails to capture: Hong Kong filmmakers seldom remained passive in the face of mainland censorship. By tweaking local formula - e.g. secularizing the supernatural; Othering vice and degeneracy - they carpentered preproduction scripts that both satisfied state censors and cleaved to Hong Kong's story specialisms.

In 1980s Hong Kong cinema, the preproduction stage coalesced around a set of predetermined elements - a cast list, a genre premise, a production deadline, a budget (Bordwell 2011: 75). A bespoke synopsis would then accommodate these ingredients. Even today, story construction at Milkyway Image is 'made to order,' says producer Shan Ding, with plot synopses tailored to an a priori production package (Bettinson 2016: 132). For the Hong Kong filmmaker, China's coproduction constraints - including its proscribed subject matter - simply constitute additional elements to which the preparatory script (or synopsis) 
must be moulded. Here again local work habits remain intact. As in Hong Kong cinema, the preliminary synopsis is formulated around a set of preconditions, only now the preconditions are multiplied by CEPA regulations. Surely, one might aver, these proliferating constraints hamper creativity. To the contrary, maintains Milkyway screenwriter Au Kin-yee: the new limitations are 'actually freeing and helpful,' supplying writers with 'puzzles' to be solved. ${ }^{18}$ From this angle, PRC proscriptions are best seen as galvanizing, not thwarting, creativity. Peter Chan adopts a philosophical outlook: 'Life is full of restrictions.' ${ }^{19}$

So much for preproduction practices. What local methods prevail during shooting? As in Hong Kong, the mainland coproductions signed by Johnnie To, Gordon Chan, Pang Hocheung and others evolve out of on-the-set story construction. No matter the PRC's mandate on preproduction screenplays, Hong Kong directors restore a shooting method that favours collaborative improvisation as the surest path to creativity. For one thing, they regard the preapproved script as provisional, a point of departure. ${ }^{20}$ During filming, the director enlists his or her cadre of actors, scenarists, and (in many cases) action choreographers to extemporize story action, fine-tune characterization, and crystallize the film's affective tone. Each night of shooting is spent collectively reworking the authorized script. ${ }^{21}$ By the end of filming, a plot has coalesced broadly resembling that limned in the preproduction screenplay; particulars of character, action, and mood, however, can deviate substantially from the preapproved script. Storyboards and shot lists, meanwhile, might be composed for CGI-laden sequences, but mostly Hong Kong directors disdain them as cramping free spontaneity. ${ }^{22}$ And multicam filming - de rigeur in Cantonese cinema - remains the Hong Kong director's preferred shooting mode. Expediency, energy, and a cascade of shot choices flow from the multicam method. In all, the PRC's coproduction system is no impediment to artistic invention. Hong Kong keynotes of collective creation and fertile improvisation, far from being effaced by mainlandization, have become the governing principles of coproduction film practice.

During shooting, moreover, Hong Kong directors try to outflank censorship. Discreetly, Peter Chan restores scenes expunged by the script censors:

SARFT executives can make us censor as much as they want during the scriptapproval process, but that doesn't mean we have to shoot their version of the script. The film is going to be censored again anyway, at the distribution-approval stage. So, I still shoot the things they ask me to remove from the script. ${ }^{23}$

Often, Chan insists, these initially expurgated scenes survive the final cut, though not without some jockeying with the postproduction censors. Like other Hong Kong filmmakers, Chan practices self-censorship only during preproduction (i.e. when anticipating nettlesome subjects); during filming, he grants himself creative autonomy, shooting without restrictions. ${ }^{24}$ Drastically reworking the script's dramaturgy could raise the censors' ire, but minor plot revisions are apt to go unnoticed: 'Censors don't go back to the approved script and compare it frame-by-frame with the film you've shot,' notes Nansun Shi. ${ }^{25}$ Thanks to the Hong Kong director's guile, censored material sometimes survives by stealth. 
In the final phase of production, a full-fledged narrative twitches and shimmies into concrete form, typifying Hong Kong cinema's penchant for postproduction plotting. Automated dialogue replacement (ADR) grants an opportunity to 'paste in' plot details, punch up lines of speech, and clarify character motivations. True, SARFT insisted on Putonghua as the lingua franca of PRC coproductions, but Hong Kong technicians had long been accustomed to dubbing films in different tongues. ${ }^{26} \mathrm{In}$ some cases, postproduction becomes an entirely Hong Kong affair. While Stanley Kwan, Pang Ho-cheung, and their compatriots populate the shooting phase with trusted Hong Kong colleagues, Johnnie To goes further: 'After [shooting], all the dubbing, editing, music - the postproduction work - is done back in Hong Kong.' Consequently, says To, 'the change to my methods is not too much' (Bettinson 2017: 26-7). Away from the scrutiny of mainland authorities, To is free to exercise individual expression, riveting postproduction tasks to entrenched local routines.

Postproduction censorship brings a fresh set of obstacles, but filmmakers once again safeguard artistic freedom by tactical means. The judicious director haggles over weighted compromises. '[The censors] may tell you to change eight things [in the director's cut],' says Peter Chan. 'You can't fight them on all eight points [but] you can fight for the two or three things that you really care about. ${ }^{, 27}$ Some directors attempt to legislate against postproduction interference by shooting alternative drafts of predictably troubling scenes - or by assembling variously risqué cuts of the film - before negotiating with the censors over the final version (Tsui 2013). According to Yuxing Zhou, 'China's dual-track censorship system...has become an obstacle for creativity' (Zhou 2015: 250), but the censorship obstacle is not insurmountable. At no stage do Hong Kong directors simply capitulate to mainland pressure. Rather, they have cultivated various ways to evade state suppression; to preserve local work methods; and to retain authorial control - all of which militates against the wholesale mainlandization of Hong Kong film practice.

Indeed, not only have Hong Kong's traditional craft practices endured; they have permeated PRC filmmaking to a great degree, substantially transfiguring mainland film practice. In part this is due to the post-CEPA influx of Hong Kong talent into China. From Stephen Chow and Wong Jing to Yuen Woo-ping and Stanley Tong, Hong Kong directors, migrating en masse, inevitably influenced mainland work practices. For a start, they cranked up production tempo. Mainland technicians, habituated to art filmmaking, had cultivated a languid, deliberative working rhythm ideally matched to an art cinema aesthetic. By contrast, Hong Kong directors, reared in the commercial cinema, hurled themselves into production with propulsive, breakneck brio. 'Hong Kong filmmakers are always like sergeants on the battlefield yelling, "Go, go, go!"” observes Gordon Chan. ${ }^{28}$ Under the aegis of Hong Kong directors, mainland technicians have learned to work at whipcrack speed.

They also gained in efficiency and organizational know-how. ${ }^{29}$ Stanley Kwan detects an increased level of technical proficiency among mainland cinematographers and art designers operating under the auspices of Hong Kong directors. ${ }^{30}$ Gordon Chan, playing the belligerent sergeant, rallies mainland comrades to his own facile routines: 'The crew needs to adapt to my way of filmmaking,' he declares. ${ }^{31}$ Mainland actors, too, had to adjust to Hong Kong-style protocols. Piecemeal plotting - constructing the story action in incremental stages 
- presented a jarring sea change to players trained in the professional Chinese theatre. So did the emphasis on improvisatory performance. Mainland actors, adept at reciting scripted lines, now had to learn to build characterization in cumulative fashion, through a gradual process of collaborative freestyling. ${ }^{32}$ In sum it is now possible to discern what critic Sek Kei calls the 'Hong Kong-ization' of mainland film practice (2013: 123) - this in contrast to the notion of mainlandization, which sees cultural influence flowing in only one direction.

\section{One Country, Many Options}

At the level of aesthetics - particularly in the realms of genre and storytelling - the new coproductions both sustain Hong Kong film heritage and expand its possibilities. Consider, firstly, genre filmmaking. Scholars attribute to China coproductions a narrowing of generic options. The PRC's strict proscriptions precludes many local genres. In China, Hong Kong directors 'are given no choices other than to dwell on the national cause' (Lee 2012: 194), their films confined 'to genres and content that carry...traditional Chinese (Confucian) ideologies' (Leung 2013: 131). Yet, genres previously unavailable to Hong Kong directors have now become live options. Encompassing a mix of epic genres, the dapian ('big film') demands not only mammoth production funds but also vast studio facilities, neither of which is readily attainable in Hong Kong. (By the 2000s many of the region's studio compounds had ceased to exist.) Until CEPA, historical blockbusters simply fell outside the infrastructural scope of Hong Kong film production. So did other extravagant genres. Highconcept science-fiction and fantasy-adventure films, such as Detective Dee: The Mystery of the Phantom Flame (2010), hardly flourished in Hong Kong's golden age, and today remain inactive in the domestic industry. Remarks producer Nansun Shi:

I couldn't have shot [the coproduced] Detective Dee in Hong Kong. It's just not viable to shoot big action productions with so few resources here. The studios have closed, the craftsmen have retired. Mainland China gives us natural resources and human resources that we don't have in Hong Kong anymore. ${ }^{33}$

Genres less outré than the fantasy-adventure film also emerged as feasible options. The Hong Kong road movie is a scarcer species than even the local fantasy blockbuster, not least because of the city's confining topography (Hong Kong being as much a vertical city as a horizontal one) ${ }^{34}$ Location permits have historically been hard to procure, rendering the domestic road movie a logistical impossibility. ${ }^{35}$ But the coproduction paradigm provides local filmmakers an entrée into this untapped genre.

More generally, the vast mainland audience - weaned both on Hong Kong imports and a venerable diet of enigmatic art cinema - encourages Hong Kong directors to furrow fresh generic terrain. For Peter Chan 'the mainland market gives me and all Hong Kong filmmakers the opportunity to make a film that Hong Kong would never dream of making' -

a film, that is, not dominated by the scenes of physical action germane to most local genres. ${ }^{36}$ To be added to these new aesthetic opportunities is the clutch of genres already extant in Hong Kong. Critics mourn the demise of Hong Kong cinema's core genres - the ghost 
movie, the crooked-cop drama, et al - but (i) these genres can be packaged as mainland coproductions, and (ii) such genres still thrive in the local production sector. Mainland coproductions have not supplanted local filmmaking; they have supplemented it. Granted, it is futile for filmmakers to propose a China coproduction 'about a corrupt Tibetan cop haunted by a ghost.' ${ }^{37}$ But Hong Kong filmmakers are free to mount such stories elsewhere, whether as wholly local productions or as non-PRC joint ventures. Contrary to prevailing thought, China coproductions have both expanded and diversified the Hong Kong filmmaker's creative palette, with no cost to aesthetic options already at the filmmaker's disposal.

Mainlandization, we are told, came to smother Hong Kong's signature genres. According to Esther C. M. Yau, 'the Cantonese film legacies and local Hong Kong stories that gave this cinema its reputation remained largely absent from the "coproduction films", (Yau 2015: 17). But many China coproductions burnish Hong Kong's film legacy. The Grandmaster (2013) and a flurry of Ip Man biopics perpetuate both Hong Kong's kung-fu genre and the local legend of Bruce Lee. Peter Chan's Wu Xia and The Warlords memorialize the Shaw Brothers' swordplay tradition. Painted Skin harks back to the Cantonese ghost film. Blind Detective (2013) flaunts the genre bending and tonal gymnastics of Hong Kong's golden age. Detective Dee: Mystery of the Phantom Flame revisits the local mystery genre, as David Bordwell points out (2011: 238). For critic Ernest Chan, the coproduced SPL 2 (2015) represents 'a quintessential Hong Kong action movie,' while a string of other joint ventures among them Unbeatable (2013) and Drug War - has 'managed to preserve the voice of Hong Kong' (2014: 133). Even Stephen Chow, now firmly embedded in mainland culture, 'didn't abandon his local zaniness entirely' (Bordwell 2011: 216). The term 'post-Hong Kong cinema' hardly befits these cases. Far from effacing Hong Kong's film heritage, many coproductions have celebrated and preserved it.

Nor is it evident, as Yau contends, that the new coproductions slight 'local Hong Kong stories' (2015: 17). In not a few cases, local issues shine forth as explicit subject matter. A Simple Life (2011), Aberdeen (2014), Trivisa (2016) - these films were volubly acclaimed (and to some extent marketed) as local expressions, yet all of them mined mainland resources and finance. Here is another foil to the charge of mainlandization. By ushering local stories into mainland cinema, Hong Kong filmmakers further 'Hong Kongized' PRC film culture. Invigorating their adoptive milieu, they stretched mainland cinema's representational parameters to new dimensions, not only by infusing the China market with local storytelling, but by pressing the limits of permissible subject matter. With growing regularity, Hong Kong directors break, or at least bend, mainland China's taboos on child trafficking (Peter Chan's Dearest [2014]), organ harvesting (Wilson Yip's Paradox [2017]; Soi Cheang's SPL 2), supernaturalism (Gordon Chan's Painted Skin), police corruption, gun violence, and the narcotics trade (Johnnie To's Drug War). Coproductions allegedly bulldoze local themes, but these films and filmmakers broach spiky topics otherwise absent from mainland screens (yet routinely plumbed at home).

Stylistic traits have endured too. Not that China coproductions haven't rung changes on Hong Kong's pre-handover film style. Most visibly, CGI has transfigured traditional martial-arts action, rendering the human body in extremis radically diffuse, or displacing it 
altogether. In the golden era, Hong Kong action movies revelled in corporeal authenticity, but the new coproductions settle for bodily fuzziness, parading 'corporeality without corpus' (Bukatman 2011: 120; emphasis in original). ${ }^{38}$ Yet, this visual tendency is properly understood as part of a global cinematic shift toward virtualization; it cannot ipso facto be adduced as evidence of mainlandization. Other visual protocols - framing, camera movement, cutting rate - similarly obey international norms. ${ }^{39}$ The visual trademarks of Wong Kar-wai and John Woo, widely pastiched in the 1990s, had by the early 2000s faded from domestic films and coproductions alike; but local stylistic traits would be assimilated to mainland film style by directors nostalgic for golden-age aesthetics. ${ }^{40}$ Critics lament the 'loss of Hong Kong style,' but local stylistic trademarks persist even in PRC coproductions.

Dramaturgically, the mainland coproductions retain basic features of Hong Kong storytelling: episodic structure, reel-by-reel plotting, tonal ruptures, motivic associations, built-in attractions, fleeting flashbacks and so on. ${ }^{41}$ Gordon Chan's Painted Skin, as Andy Willis observes, possesses a 'disjointed' narrative structure, the sheer blatancy of which supplies its detractors with proof of 'poor filmmaking' (Willis 2011: 25). Willis, however, attributes the story's formal idiosyncrasy not to shoddy plotting but to the PRC's industrial constraints. For Willis, Chan's effort to avert mainland censorship honeycombs the very structure of Painted Skin's plot. He writes: '[Censorship] constraints force [Gordon Chan] to move away from conventional cause and effect narrative structures and towards a much more episodic, picaresque, and disjointed structure' (25). Willis's hypothesis seems to me plausible: Chan most likely deployed circumvention tactics of the kind I described earlier. But we could also grasp Painted Skin's episodic plotting - along with its abrupt tonal detours and genre digressions - as reflecting Chan's fidelity to local storytelling norms, even as he embraces the more recent innovations of transnational cinema (e.g. CGI).

Consider one more instance. Tsui Hark's Detective Dee: Mystery of the Phantom Flame displays a rigorous reel-by-reel construction. Tsui devotes the opening reels to attention-getting spectacle and narrative exposition. The first two reels establish the principal locales (the imperial palace; the towering Buddha statue), introducing the protagonists and launching the central plot imbroglio. Scattered through these reels is a recurring motif (a set of sacred amulets); Tsui enlists this MacGuffin not only to motivate story action but to yoke distinct blocks of action. By the third reel, a long-range goal has crystallized: Detective Dee (Andy Lau) must solve a puzzling case of random human combustion (the 'phantom flame' of the title). A band of suspects coalesces. New motifs (e.g. Dee's potent mace) acquire saliency, to be braided through subsequent episodes. The fourth reel furnishes a bust-up; thereafter most subsequent reels will showcase chase-and-fight spectacle. A new goal is introduced near the film's midpoint (reel seven), infusing the plot with fresh impetus.

As Dee's investigation deepens, tantalizing flashbacks dovetail reels five through eight, hinting at a solution to the crime. By now the plot teems with motifs; together with flashbacks revisiting earlier scenes, they bolster the plot's coherence. With the climax looming, Tsui ends reels nine and ten with dangling causes and cliff-hanger scenarios, ratcheting suspense. He packs the climactic reel with the film's major elements - the central locales (the palace, the giant Buddha), the main protagonists, and the cohesive motifs 
(including another high-stakes chase). The final reel consists of a brief epilogue, supplying the sort of formal symmetry that Hong Kong scenarists began to favour by the 1990s.

In short, Tsui's plotting hews to episodic principles derived from local cinema. Moreover, each reel is shot through with Hong Kong's aesthetic traits. Tonal ruptures? At the tail-end of reel three, the drama ricochets from romantic encounter to comic skit to physical skirmish, creating a blizzard of tonal shifts and jarring actions. Percussive fight sequences? Tsui's combat scenes, steeped in kung-fu and wuxia iconography, adopt the 'pause/burst/pause' rhythm prevalent within local action cinema. ${ }^{42}$ There are allusions, too, to Tsui's golden-age milestones - most explicitly, Zu: Warriors from the Magic Mountain (1983), A Chinese Ghost Story (1987), and Once Upon a Time in China (1991). In all, Detective Dee gives the lie to the mainlandization thesis, proponents of which presuppose a pugilistic opposition between locally-produced filmmaking and mainland coproduction. Rather, the local is now so deeply imbricated with mainland cinema as to almost subjugate it. We do better, I submit, to regard coproductions not as an antithesis to local filmmaking but rather as a complement to it, ushering 'Hong Kong cinema' - a mutable category, to be sure toward uncharted creative territory.

\section{A Better Yesterday}

So far I have held in abeyance the question of quality. If traditional Hong Kong practices and aesthetics have endured, why are the new coproductions inferior to pre-handover movies? How to account for the startling slump in standards? For some critics, mainland censorship is the prime villain: '[Beijing's] inane meddling only pushes down the quality of commercial films produced in China' (Sebag-Montefiore 2013). Also to blame is the vapid, corpulent dapian. Assigned to orchestrate military costume dramas (Red Cliff [2008]) and main-melody sagas (The Founding of an Army [2017]), Hong Kong directors now peddle Communist hagiography and 'national glorification' (Yeh and Davis 2008: 48), trading artistry for agitprop. Alternatively, obsessive recycling - driven by the avaricious filmmaker's 'mercenary' appetites - is at the root of post-handover cinema's 'general mediocrity,' as when directors rehash their past work for mainland consumption (Yau 2015: 21). ${ }^{43}$ At best, mainland coproductions serve up reheated meals; the Hong Kong golden age furnished feasts.

But this perspective, widely held as it is, is too crude. For one thing, the golden age generated hundreds of films, many of them 'program fillers' of negligible quality. For every Hard Boiled (1992) and God of Gamblers (1989) there was a Vampire Buster (1989) and a Basic Impulse (1992), midrange movies registering little or no impact on the culture. Moreover, the golden era profited from a late-1980s production surge, with local studios grinding out approximately 250 films per year. Today, Hong Kong's annual film output hovers at around 50-60 titles. We shouldn't be surprised, then, if new masterworks are in relatively short supply. Nor should we expect traditional craft practices to automatically yield riches: works of varying quality can spring from identical work routines. 
Finally, I would suggest that the post-handover years, dominated by PRC coproductions, have not been as artistically barren as critical mass indicates. In the Mood for Love (2000), Crouching Tiger, Hidden Dragon (2000), Shaolin Soccer, Kung Fu Hustle (2004), Red Cliff, Ip Man (2008), Bodyguards and Assassins (2009), A Simple Life, Drug War, The Grandmaster, The Taking of Tiger Mountain (2014), Our Time will Come (2017) one can quibble as to the relative merits of these joint ventures, but taken as a whole, I submit, they bear comparison with Hong Kong films from any period. Our diagnosis of the post-handover industry looks healthier still when we admit local productions. Here is a sampling: Beast Cops (1998), Infernal Affairs, Election, The Way We Are (2008), Love in a Puff (2010), Gallants (2010), Rigor Mortis (2013), The Midnight After (2014), Port of Call (2015), Ten Years (2015). Against such evidence, the dystopian claims of mainlandization, post-Hong Kong cinema, and the demise or disappearance (or even just the sunken quality) of Hong Kong filmmaking look feeble indeed.

The mainlandization thesis is vulnerable on other grounds. First, there is the topos of disappearance itself, surely by now at a point of critical fatigue. Critics date the onset of Hong Kong cinema's disappearance to at least 1984, in which year the transfer of sovereignty was enshrined in the Joint Declaration. Today, we are told, the territory's filmic identity is still receding. Put glibly, Hong Kong cinema is performing the slowest vanishing act in movie history. The disappearance premise is of negligible value, because of its repetitiveness no less than because of its unfalsifiability. Second, the mainlandization thesis flirts with cultural essentialism. What do critics mean by Hong Kong's 'unique' or 'singular' identity? Where to locate this cinema's distinctive 'aura,' 'spirit,' or 'cultural odour'? (Leung 2013: 134). Evidently, these critics intend to evoke the aesthetic style governing Hong Kong's golden-age cinema. But this gilded aesthetic can lay no greater claim to Hong Kong's cinematic identity than can the social-realist stylistics of the Hong Kong New Wave, or the hyper-reality of the 1960s Shaw Brothers wuxia cycle, or the effervescent narration of the classic Cantonese musical. Lastly, the mainlandization thesis is underpinned by a denunciation of PRC censorship: Hong Kong auteurs are artistically stifled by mainland prohibitions. It bears recalling, though, that Hong Kong filmmakers are not unbridled by censorship even in the domestic sphere. The local film industry's ratings system may be less straitened than Beijing's content controls, but it is nevertheless a form of censorship, and the Hong Kong Board of Classification has, in not a few cases, imposed itself upon even Category III (adult-oriented) films.

To detractors of the coproduction trend might be posed a counterfactual scenario. What fate would have befallen Hong Kong cinema had its leading filmmakers not embarked on mainland coproductions in the early 2000s? It's not hard to imagine the industry continuing the precipitous decline with which it entered the new century. Perhaps then we would truly have been faced with a post-Hong Kong cinema. Instead, the coproduction system stabilized a declining local industry, rejuvenating Hong Kong cinema by posing filmmakers a fresh bundle of challenges, both logistical and artistic. These filmmakers, in turn, have responded not with simple intransigence, doggedly sticking to time-worn 
techniques. Rather, they have adapted local traditions to contemporary market demands and production exigencies, innovating on past formulas.

According to many commentators, Hong Kong filmmakers navigate the coproduction system by means of survival strategies. I hope to have shown the inadequacy of this axiom. Hong Kong filmmakers have not been merely surviving in China; rather, they have challenged and even changed industrial policies (prizing open crevices in the censorship system, for instance); they have actively moulded mainland craft practices to Hong Kong work methods; and they have innovated stories and styles, adapting local genres to new production conditions. We could go further. It may not be too far-fetched to see in Hong Kong filmmakers' preservation of local elements - as well as in their tactics of subterfuge and circumvention - a tacit form of resistance against mainland imperialism. Regardless of actual intent, their assertion of local tradition constitutes nothing less than a political act at a period in which these very traditions are perceived to be under threat.

Until 2018 SARFT (latterly SAPPRFT) supervised mainland coproductions. Today this task falls to the Communist Party's propaganda department (or its 'publicity' department, to use CCP rhetoric). Prima facie this manoeuvre signals a tightening of regulatory controls. Yet still I think the announcement of a post-Hong Kong cinema is premature. Hong Kong's film industry has not so much broken with its past traditions as channelled them into distinct modes of production. Today's filmmakers toggle between Hong Kong and the mainland, opting for one or other mode of production as artistic and commercial priorities dictate. Those claiming that Hong Kong cinema has been demolished or diminished by recent industrial change err in their judgement; not least, they underestimate the resourcefulness and ingenuity of Hong Kong filmmakers. Despite claims to the contrary, the fertile legacies of Hong Kong cinema live on.

\section{References}

Bettinson, Gary. 2017. "Co-Production, Censorship, and Chinese Democracy: An Interview with Johnnie To." Cineaste 42 (4): 25-27.

2016. "Hong Kong Puzzle Films: The Persistence of Tradition," in Gary

Bettinson and James Udden (eds) The Poetics of Chinese Cinema, 119-145. New York: Palgrave Macmillan.

2008. "New Blood: An Interview with Soi Cheang." Journal of Chinese

Cinemas 2 (3): 211-224.

Bordwell, David. 2011. Planet Hong Kong: Popular Cinema and the Art of Entertainment. $2^{\text {nd }}$ ed. Madison: Irvington Way Institute Press. 
Bukatman, Scott. 2011. "Why I Hate Superhero Movies.” Cinema Journal 50 (3): 118-122.

Chan, Ernest. 2014. "From Co-productions to Team Local: Hong Kong Cinema 2013," in Li Cheuk-to (ed.) The $38^{\text {th }}$ Hong Kong International Film Festival Catalogue, 131-133. Hong Kong: Hong Kong International Film Festival Society.

Chu, Yiu-wai. 2015. "Toward a New Hong Kong Cinema: Beyond Mainland-Hong Kong Co-productions." Journal of Chinese Cinemas 9 (2): 111-124.

Lam, Perry. 2011. Once A Hero: The Vanishing Hong Kong Cinema. Hong Kong: East Slope Publishing.

Lau, Dorothy Wai Sim Lau. 2018. Chinese Stardom in Participatory Cyberculture.

Edinburgh: Edinburgh University Press.

Lee, Bono. 2012. "The Possibility of China for Hong Kong Directors: The Transformation of Peter Chan's Identity," in Peter Ho-Sun Chan: My Way, edited by Li Cheuk-to, 187-195. Hong Kong: Joint Publishing.

Leung Yuk Ming, Lisa. 2013. "Re-nationalizing the Transnational? The Cases of Exiled and Warlords in Hong Kong-China Film Coproduction," in Nissim Otmazgin and Eyal Ben-Ari (eds) Popular Culture Coproductions and Collaborations in East and Southeast Asia, 115135. Singapore and Japan: NUS Press.

Leung Wing-Fai. 2008. "Infernal Affairs and Kung Fu Hustle: Panacea, Placebo and Hong Kong Cinema," in Leon Hunt and Leung Wing-Fai (eds), East Asian Cinemas: Exploring Transnational Connections on Film, 71-87. London: I. B. Tauris.

Myers, Steven Lee, and Amy Cheng. 2017. "68 Things You Cannot Say on China's Internet." The New York Times, 24 September. https://www.nytimes.com/2017/09/24/world/asia/chinainternet-censorship.html

Pang, Laikwan. 2011. “The State Against Ghosts: A Genealogy of China's Film Censorship Policy." Screen 52 (4): 461-476.

Sala, Ilaria Maria. 2016. “"No Ghosts. No Gay Love Stories. No Nudity’: Tales of FilmMaking in China." The Guardian, 22 September.

https:/www.theguardian.com/film/2016/sep/22/tales-of-film-making-in-china-hollywoodhong-kong

Sebag-Montefiore, Clarissa. 2013. "When Movie Money Talks.” The New York Times, April 26. https://latitude.blogs.nytimes.com/2013/04/26/chinas-censors-push-down-quality-offilms/

Sek Kei. 2013. "Is Hong Kong Becoming Like the Mainland, or Vice Versa?" in The $37^{\text {th }}$ Hong Kong International Film Festival 2013, 123-125. Hong Kong: Hong Kong International Film Festival Society. 
Szeto, Mirana M., and Yun-chung Chen. 2013. "To Work or Not to Work: The Dilemma of Hong Kong Film Labor in the Age of Mainlandization," Jump Cut: A Review of Contemporary Media 55, http://ejumpcut.org/archive/jc55.2013/SzetoChenHongKong/

Teo, Stephen. 2008. "Promise and Perhaps Love: Pan-Asian Production and the Hong KongChina Interrelationship." Inter-Asia Cultural Studies 9 (3): 341-358.

Tsui, Clarence. 2019. "Hong Kong Cinema is Not Dead, as Recent Chinese Box Office Successes Show." South China Morning Post, 29 August.

https://www.scmp.com/magazines/post-magazine/arts-music/article/3024826/hong-kongcinema-not-dead-recent-chinese-box

Tsui, Clarence. 2013. “Cannes: Johnnie To on the 'Anxiety' of Censors, Challenges of Making a Film in Mainland China (Q\&A).” The Hollywood Reporter, 15 May. https://www.hollywoodreporter.com/news/cannes-johnnie-anxiety-censors-challenges$\underline{523270}$

Willis, Andy. 2011. "Painted Skin: Negotiating Mainland China's Fear of the Supernatural." Asian Cinema 22 (1): 20-30.

Yau, Esther C. M. 2015. "Watchful Partners, Hidden Currents: Hong Kong Cinema Moving into the Mainland of China," in A Companion to Hong Kong Cinema, edited by Esther M. K. Cheung, Gina Marchetti, and Esther C. M. Yau, 17-50. West Sussex: Blackwell.

Yau, Herman Lai To. 2015. The Progression of Political Censorship: Hong Kong Cinema from Colonial Rule to Chinese-Style Socialist Hegemony. $\mathrm{PhD}$ thesis, Lingnan University.

Yeh, Emilie Yueh-yu, and Darrell William Davis. 2008. "Re-nationalizing China's Film Industry: Case Study on the China Film Group and Film Marketization." Journal of Chinese Cinemas 2 (1): 37-51.

Zhou Yuxing. 2015. "Pursuing Soft Power Through Cinema: Censorship and Double Standards in Mainland China.” Journal of Chinese Cinemas 9 (3): 239-252.

\section{Notes}

\footnotetext{
${ }^{1}$ See Berenice Reynaud (1990) https://www.nytimes.com/1990/05/13/movies/film-china-sshadow-falls-across-hong-kong-s-films.html (accessed 23 March 2019). Hong Kong-PRC coproductions from the early 1980s include Shaolin Temple (1984), Reign Behind the Curtain (1983), and Burning of the Imperial Palace (1983) (see Leung 2013 p. 118).

${ }^{2}$ Interview with Bey Logan, 29 March 2016.
} 
${ }^{3}$ During the CEPA era, the State Administration of Radio, Film and Television (SARFT) supervised the country's media industries. Among its branches was the China Film Bureau, the chief censoring agency monitoring all films produced by and released in mainland China. In 2013 SARFT assimilated publishing to its purview, thereafter becoming known by the bloated acronym SAPPRFT (State Administration of Press, Publications, Radio, Film and Television). SAPPRFT was abolished in 2018, whereupon film censorship fell under the jurisdiction of the Communist Party's publicity department.

${ }^{4}$ Anon (2002) 'China Bans Football Comedy,' News24.com (26 April) https://www.news24.com/xArchive/Archive/China-bans-football-comedy-20020426 (accessed 31 May 2018).

${ }^{5}$ For useful discussions of Hong Kong cinema's 'survival strategies,' see Stephen Teo (2008) p. 345; Esther C. M. Yau (2015) p. 21; and Leung Wing-fai (2008) pp. 71-87. On selfdiscipline as defined by Communist Party officials, see Myers and Cheng (2017).

${ }^{6}$ Bordwell (2011) p. 241; p. 195; Lee (2012) p. 195.

${ }^{7}$ Sala (2016); Teo (2008) p. 346.

${ }^{8}$ Interview with Pang Ho-cheung, 31 March 2016.

${ }^{9}$ This void, critics argue, has yet to be filled by a new generation of directors. The mercenary veteran filmmakers, meanwhile, deny opportunities to young Hong Kong directors by dominating the coproduction sphere. Not to be overlooked, however, is a flurry of emerging local filmmakers: Jevons Au, Vicky Wong, Frank Hui, Amos Why, Wong Chun, Fire Lee, Derek Tsang, and Adam Wong, among others. Nor have senior directors slighted the newcomers. Johnnie To, for instance, founded the Fresh Wave short film competition in order to nurture new talent. Granted, few of the new directors have helmed PRC coproductions; and not every filmmaker recounts a smooth passage through Beijing's censorship machinery (e.g. Yau 2015). On the other hand, To, Peter Chan, Tsui Hark, and other seasoned directors unlike their inexperienced protégés - possess the box-office weight and bargaining power to push China's film industry toward liberalization.

${ }^{10}$ Interview with Nansun Shi, 23 March 2016.

${ }^{11}$ For further information, see Szeto and Chen (2013: 13); and Bettinson (2016). In the early years of CEPA coproductions, Tsui Hark hired mainland writers to manufacture the script for preproduction censorship review. Though these customised screenplays were not radically different from the story Tsui intended to shoot, they did not constitute the shooting script. 'The story was the same,' testifies Tsui's producer, Nansun Shi. 'But the wording was different. These writers have been working in China for so long, they know how to write it; they know what words to use in order to satisfy the censors, and they wrote the scenes in a way that looked milder and less contentious.' Interview with Nansun Shi, 23 March 2016.

${ }^{12}$ Interview with Pang Ho-cheung, 31 March 2016. Likewise, Herman Yau 'avoided all the sensitive and "risky" content in the screenplay' of The Woman Knight of Mirror Lake (2011). Yau (2015) p. 291.

${ }^{13}$ Ibid.; interview with Nansun Shi, 23 March 2016. 
${ }^{14}$ Interview with Nansun Shi, 23 March 2016.

${ }^{15}$ Interview with Gordon Chan, 17 April 2017. See also Laikwan Pang (2011) p. 472.

${ }^{16}$ Interview with Nansun Shi, 23 March 2016. Pang Ho-cheung devised a zombie-themed coproduction around this very conceit: 'I am allowed to shoot the zombie element as long as the audience knows that the zombies aren't real but exist only in the character's mind,' he says. 'This is how I solve the problem of censorship.' Interview with Pang Ho-cheung, 31 March 2016.

${ }^{17}$ Interview with Gordon Chan, 17 April 2017.

${ }^{18}$ Interview with Au Kin-yee, 5 April 2014.

${ }^{19}$ Interview with Peter Chan, 3 April 2014.

${ }^{20}$ Ibid.; interview with Gordon Chan, 17 April 2017.

${ }^{21}$ Interview with Gordon Chan, 17 April 2017; interview with Au Kin-yee, 5 April 2014; interview with Shan Ding, 5 April 2014.

${ }^{22}$ Interview with Pang Ho-cheung, 31 March 2016; interview with Peter Chan, 3 April 2014.

${ }^{23}$ Interview with Peter Chan, 3 April 2014.

${ }^{24}$ Ibid.; interview with Johnnie To, 11 April 2017; interview with Herman Yau, 12 April 2017.

${ }^{25}$ Interview with Nansun Shi, 23 March 2016.

${ }^{26}$ Interview with Peter Chan, 3 April 2014.

${ }^{27}$ Ibid. For elaboration, see Bettinson 2016: 39.

${ }^{28}$ Interview with Gordon Chan, 17 April 2017.

${ }^{29}$ Interview with Nansun Shi, 23 March 2016; interview with Gordon Chan, 17 April 2017.

${ }^{30}$ Interview with Stanley Kwan, 14 April 2017.

${ }^{31}$ Interview with Gordon Chan, 17 April 2017.

${ }^{32}$ Ibid.

${ }^{33}$ Interview with Nansun Shi, 23 March 2016.

34 'In Hong Kong,' states director Soi Cheang, 'it's very difficult to make a road movie, because Hong Kong is so small - we just get to everywhere too soon, too quickly. So, we don't have an opportunity to do that kind of movie' (Bettinson 2008: 221). 
${ }^{35}$ Soi Cheang's locally-mounted Motorway (2012) flaunts auto-race sequences filmed in actual Hong Kong streets, but (according to writer Joey O'Bryan) Cheang shot these scenes illegally, without government permission. (Interview with Joey O'Bryan, 20 April 2013.) The film's producer, Shan Ding, contends that location permits remain hard to obtain, despite CEPA's apparent liberalization of local film production. (Interview with Shan Ding, 5 April 2014.)

${ }^{36}$ Interview with Peter Chan, 3 April 2014.

${ }^{37}$ Interview with Nansun Shi, 23 March 2016.

${ }^{38}$ Scott Bukatman here describes a tendency as it relates to Hollywood's superhero cinema. See Dorothy Wai Sim Lau (2018) for discussion of this phenomenon in Chinese-language cinemas.

${ }^{39}$ These protocols - aligning with what Bordwell calls intensified continuity - govern Hong Kong's local cinema as well as its China coproductions.

${ }^{40}$ Soi Cheang and Peter Chan, for instance, imported the rapid-zoom device that saturated myriad Shaw Brothers movies. Interview with Peter Chan, 3 April 2014. Also see Bettinson (2008), pp. 222-223.

${ }^{41}$ See Bordwell (2011).

${ }^{42}$ David Bordwell identifies a distinctive movement rhythm - a pause/burst/pause pattern governing Hong Kong cinema’s action sequences. Bordwell (2011) p. 140.

${ }^{43}$ In Detective Dee: Mystery of the Phantom Flame, Bordwell argues, Tsui Hark revisits the terrain he ploughed in The Butterfly Murders (1979) 'with surprisingly academic results' (2011: 238). One might note a paradoxical argument lurking within the mainlandization thesis, namely, that Hong Kong filmmakers at once abandon local traditions and recycle their past successes. 